\title{
Comparative Effects of Breed and Sex on Carcass and Organ Profiles of Duck (Anas plantrynychos) and Guinea Fowl (Numidia meleagris) in Abeokuta, Ogun State, Nigeria
}

\author{
Apata E. S. ${ }^{1}$, Koleoso I. M. ${ }^{1}$, Taiwo B. B. A. ${ }^{1}$, Okubanjo A. O. ${ }^{2} \&$ Tijani L. A. ${ }^{3}$ \\ ${ }^{1}$ Meat Science Laboratory, Department of Animal Production, Olabisi Onabanjo University, Yewa Campus, \\ Ayetoro, Ogun State, Nigeria \\ ${ }^{2}$ Department of Animal Science and Industrial Technology, Babcock University, Ilishan-Remo, Ogun State, \\ Nigeria \\ ${ }^{3}$ Department of Animal Production, Lagos State Polytechnic, Ikorodu, Nigeria \\ Correspondence: Apata, E. S., Department of Animal Production, Olabisi Onabanjo University, Yewa Campus, \\ P.M.B 0012, Ayetoro, Ogun State, Nigeria. E-mail: ebunoluapata2008@yahoo.com
}

Received: June 10, 2014 Accepted: September 28, 2014 Online Published: October 13, 2014

doi:10.5539/sar.v3n4p107 URL: http://dx.doi.org/10.5539/sar.v3n4p107

\begin{abstract}
Carcass and organs characteristics of two breeds and sexes of poultry which include Duck and Guinea fowl (GF) were investigated. A total of twenty four matured birds with twelve from each breed were used for this study in a $2 \times 2$ (Breed $\times$ Sex) factorial arrangement in a completely randomized design. The birds were slaughtered in batches of four properly bled, defeathered and dressed, the carcasses and organs weighed. The birds carcasses were chilled at $4{ }^{\circ} \mathrm{C}$ for $24 \mathrm{hrs}$ prior to fabrication into primal cuts. The results showed that duck had higher $(\mathrm{P}<0.05)$ carcass and organs weight and percentages than GF, also males irrespective of the breed gave higher $(\mathrm{P}<0.05)$ carcass and organs weight and percentages than their female counterparts. At interaction level male ducks still gave higher $(\mathrm{P}<0.05)$ cut-up parts weight and percentages than female, while female GF elicited higher $(\mathrm{P}<0.05)$ primal cuts weight and percentages. It was observed from this study that Duck and GF carcass and organs cut-up parts were heavy enough to supply needed protein like chicken. These birds can therefore, be integrated into commercial poultry production to make animal protein more available to consumers.
\end{abstract}

Keywords: breed, sex, duck, guinea fowl, carcass, organs, Abeokuta metropolis

\section{Introduction}

The developing countries of the world have not been able to meet animal protein requirements of the populace. This is because the problem of protein malnutrition is enormous in these nations (Atteh, 2004). Food and Agricultural Organization (FAO) recommended a minimum of $70 \mathrm{~g}$ protein intake daily per caput out of which $35 \mathrm{~g}(50 \%)$ must come from animal protein but an average individual in developing countries including Nigeria consumes less than $10 \mathrm{~g}$ of protein with only $3.2 \mathrm{~g}$ of this emanating from animal protein (FAO, 2006). Successive government policies and programmes to boost sustainable livestock production in developing countries have only been centred on cattle and small ruminants production with no pragmatic solution to her problem of animal protein deficiency (Aduku \& Olukosi, 1990). The only plausible approach to achieving the noble goal of providing quality protein for all in the developing countries is the development of poultry sub-sector which is the fastest means to bridge protein deficiency gap due to short generation interval of poultry (Gbadamoshi \& Egbumke, 1999). In developing poultry sector, other species beside domestic fowl should be considered such as Duck, (Anas plantrynychos) and Guinea fowl (Numidia meleagris) which are found in various ecological zones of Nigeria and other developing countries with high carcass and organs yield (Yusuf, 1995; Omojola, 2007) without taboos hindering the consumption of their meats (Ireobi et al., 1999). Chicken have been extensively studied and exploited, there is the need therefore, to study other poultry species such as Duck and Guinea fowl for their nutritional potentialities. This study is aimed at evaluating the carcass and organs characteristics of Duck and Guinea fowl (GF) found in Abeokuta metropolis as influenced by their breed and sex. 


\section{Materials and Methods}

\subsection{Experimental Birds}

Twenty four matured birds of weight ranged between 921-1600 g twelve of each breed (Duck and Guinea fowl) 12 males and 12 females were purchased from markets in Abeokuta metropolis and were transported to the Meat Science Laboratory of the Department of Animal Production, Olabisi Onabanjo University, Yewa Campus, Ayetoro, Ogun State where this study was carried out. The birds were rested for two weeks during which period they were fed maize, guinea corn and water ad-libitum. They were also given antistress medicament.

\subsection{Slaughtering of Birds}

The birds were starved for 16 hours during which clean and enough water was given to the birds. They were weighed to obtain their fasted weight. They were sticked by severing the jugular vein and carotid at neck region arteries and their carcasses were bled for 30 mins and their bled and blood weights determined (Omojola et al., 2004).

\subsection{Dressing and Fabrication of Birds Carcasses}

The birds carcasses were scalded, defeathered and singed and weighed to get defeathered weights. They were eviscerated and weighed to obtain dressed carcass weights. The carcasses were chilled at $4{ }^{\circ} \mathrm{C}$ for $24 \mathrm{hrs}$ and were fabricated into following cut-up parts-thigh, drumstick, hindback, foreback, breast, wing and neck (Aduku \& Olukosi, 2000).

\subsection{Measurements on Carcasses and Organs}

2.5 Dressing Percentage/Yield: This was determined according to Aduku and Olukosi (2000) Thus

$$
\text { Dressing } \%=\frac{\text { Dressed carcass weight }}{\text { Fasted live weight }} \times 100
$$

\subsection{Percentage Cut-Up Parts Was Determined as:}

$$
\frac{\text { Cut-up part weight }}{\text { Carcass weight }} \times 100
$$

Weights of carcasses and organs were measured using the kitchen scale and their weight values were expressed in grams.

\subsection{Experimental Design}

The experiment was completely randomized with $2 \times 2$ factorial arrangement. Two treatments (Duck and Guinea fowl), two factors (Male and Female) and replicated three times.

\subsection{Statistical Analysis}

Data collected from this study were subjected to analysis of variance (ANOVA) using (SAS, 2002) and the significant differences among the means were separated with Duncan Multiple range test of the same statistical system.

\section{Results and Discussion}

Duck had higher $(\mathrm{P}<0.05)$ fasted, bled, defeathered, heart as well as head and leg weights, while guinea fowl (GF) carcasses furnished higher $(\mathrm{P}<0.05)$ liver, gizzard and blood weights (Table 1). The results revealed that males birds either duck or guinea fowl had higher $(\mathrm{P}<0.05)$ weights of all the variables measured while the females had lower $(\mathrm{P}<0.05)$ variables. At the interaction level, the same results of male having higher $(\mathrm{P}<0.05)$ variables were observed between breeds while within the breed male duck had higher $(\mathrm{P}<0.05)$ variables still and female guinea fowl had higher $(\mathrm{P}>0.05)$ variables except head and leg weights that were higher $(\mathrm{P}<0.05)$ in male while both male and female GF had the same $(\mathrm{P}>0.05)$ liver, and blood weights. Omojola (2007) reported higher live and cut-up parts (primal cuts) weights for male Duck against female as obtained in this study. The higher live weight observed between duck and GF could be due to breed effect. Duck could be naturally heavier compared with GF, but the heavier liver, gizzard and blood of GF could be due to the fact that GF make longer flight than duck and could require bigger liver, more blood and food to be processed for higher energy in the gizzard as observed in this study. It was observed in this study that female GF had higher carcass variables than its male counterpart except head and leg which were higher in male GF, while their liver weights are the same. The results could be because the female GF possesses those characteristics to be able to perform the functions of breeding and flight (Nwagu \& Alawa, 1995). Table 2 shows the percentages of carcasses and organs of duck and GF as influenced by sex. Guinea fowl by breed had higher $(\mathrm{P}<0.05)$ percentages of bled, and defeathered weights while Duck had 
higher $(\mathrm{P}<0.05)$ heart, blood, head and leg weight percentages. There were no significant $(\mathrm{P}>0.05)$ differences in liver and dressing percentages between Duck and GF. But within sex, females either of Duck or GF had higher $(\mathrm{P}<0.05)$ bled, defeathered and dressed weight percentages, while males either of Duck or GF had higher $(\mathrm{P}<0.05)$ heart and blood percentages. At the level of interaction male Duck had higher $(\mathrm{P}<0.05)$ dressing as well as heart, blood, head and leg weight percentages $68.50 \pm 2.94$ against $67.26 \pm 3.28$ for GF percentage, while male GF had higher $(\mathrm{P}<0.05)$ bled and defeathered weight percentages $95.76 \pm 1.91,86.75 \pm 3.66$ against $92.02 \pm 2.40$ and $82.80 \pm 2.60$ for male Ducks. Female GF had higher $(\mathrm{P}<0.05)$ dressing and bled weight percentage, while female duck had higher $(\mathrm{P}<0.05)$ heart, head and leg weight percentages. The results showed that within breed, female duck had higher $(\mathrm{P}<0.05)$ bled and defeathered weight percentages, while male had higher $(\mathrm{P}<0.05)$ heart and blood weight percentages but the same $(\mathrm{P}>0.05)$ liver, gizzard, head and leg as well as dressing weight percentages with its female counterpart. Female GF had higher $(\mathrm{P}<0.05)$ bled, heart and dressing weight percentage, but the same $(\mathrm{P}>0.05)$ defeathered, heart, liver, gizzard, head and leg weight percentages with its male counterpart, while the male GF had higher $(\mathrm{P}<0.05)$ blood weight percentage than female GF. The results of carcass and organs percentages observed in this study compared well with those reported for male and female chicken by Carew et al. (1998) and Omojola et al. (2004).

The results of different cut-up parts weights for Duck and GF are presented on Table 3. Duck furnished higher $(\mathrm{P}<0.05)$ primal cuts than GF. Also males irrespective of breed had higher $(\mathrm{P}<0.05)$ cut-up parts than females. The results showed that at the level of interaction male Duck had higher $(\mathrm{P}<0.05)$ cut-up parts than male GF, also the female Duck had higher $(\mathrm{P}<0.05)$ primal cuts than its GF counterpart except in weight of thigh $(70.62 \pm 72.62)$ against (94.77 \pm 22.84$)$ for GF thigh cut. Within breeds, the results indicated that male Duck had higher $(\mathrm{P}<0.05)$ primal cuts weight than female Duck, while female GF primal cuts were higher $(\mathrm{P}<0.05)$ than those of male GF cuts except in the neck $(42.98 \pm 12.62)$ against $(44.72 \pm 15.83)$ for male GF neck. The results of higher cut-up parts for male against lower values for female poultry breeds observed in this study were reported by Omojola (2007). However, the reason for higher primal cuts in female GF than in male could be due to differences in live weight of male and female GF with female having higher live weight. The results of percentage weight of cut-up parts of Duck and GF as affected by sex are shown on Table 4. There were no significant $(\mathrm{P}<0.05)$ differences in percentage weight of breast, foreback and hindback between Duck and GF breeds (Nwachuku, 1998). However, GF had higher $(\mathrm{P}<0.05)$ percentage weight for thigh $(15.29 \pm 1.17)$ and drumstick $(12.35 \pm 2.03)$ against $8.46 \pm 2.01)$ and 10.76 \pm 1.25 for thigh and drumstick percentage weight in Duck. But gave higher $(\mathrm{P}<0.05)$ percentage weight in wing and neck cuts with $21.70 \pm 3.68$ and $8.54 \pm 1.26$ against $15.53 \pm 3.69$ and $7.35 \pm 2.16$ for GF. There were no significant $(\mathrm{P}<0.05)$ differences between the cut-up parts irrespective of the sex of Duck and GF, but at the level of interaction Duck male had higher $(\mathrm{P}<0.05)$ foreback, hindback and wing cuts percentage weights than GF, while GF male had higher $(\mathrm{P}<0.05)$ percentage weights of thigh and drumstick cuts than it was obtained for male Duck. Within the breeds female Duck had higher $(\mathrm{P}<0.05)$ breast and thigh $(28.53 \pm 0.70)(9.18 \pm 0.78)$ percentage weight, while the male Duck had higher $(\mathrm{P}<0.05)$ foreback percentage weight $(11.97 \pm 2.17)$. Also, female GF had higher $(\mathrm{P}<0.05)$ breast, $(28.51 \pm 1.92)$ and hindback $(11.59 \pm 0.60)$, male GF had higher $(\mathrm{P}<0.05)$ thigh $(16.13 \pm 0.45)$ and drumstick (13.39 \pm 0.73$)$ percentage weights, while other cut-up parts showed no significant $(\mathrm{P}>0.05)$ difference in percentage weight. These results could be due to higher live and carcass weights of female GF which were manifested in cut-up parts. 
Table 1 . Weight of carcasses and organs of duck and guinea fowl as influenced by breed and sex

\begin{tabular}{|c|c|c|c|c|c|c|c|c|}
\hline \multicolumn{9}{|c|}{ Variable } \\
\hline Parameter & FW (g) & $\operatorname{BLW}(\mathrm{g})$ & $\operatorname{DFW}(\mathrm{g})$ & $\mathrm{HW}(\mathrm{g})$ & $\mathrm{LW}(\mathrm{g})$ & $\mathrm{GW}(\mathrm{g})$ & $\operatorname{BLDW}(\mathrm{g})$ & $\operatorname{HLW}(\mathrm{g})$ \\
\hline \multicolumn{9}{|l|}{ Breed } \\
\hline DK & $1600 \pm 474.58^{\mathrm{a}}$ & $1495.83 \pm 418.58^{\mathrm{a}}$ & $1060.88 \pm 317.31^{\mathrm{a}}$ & $13.58 \pm 4.73^{\mathrm{a}}$ & $10.54 \pm 3.04^{\mathrm{b}}$ & $10.15 \pm 2.93^{\mathrm{b}}$ & $23.03 \pm 6.65^{\mathrm{b}}$ & $129.19 \pm 45.90^{\mathrm{a}}$ \\
\hline GF & $921.67 \pm 121.34^{b}$ & $875.83 \pm 124.99^{\mathrm{b}}$ & $620.08 \pm 114.26^{\mathrm{b}}$ & $4.20 \pm 1.24^{\mathrm{b}}$ & $13.99 \pm 2.33^{\mathrm{a}}$ & $19.46 \pm 1.55^{\mathrm{a}}$ & $56.49 \pm 8.31^{\mathrm{a}}$ & $56.23 \pm 5.79^{\mathrm{b}}$ \\
\hline \multicolumn{9}{|l|}{ SEX } \\
\hline M & $813.92 \pm 877.14^{\mathrm{a}}$ & $752.21 \pm 602.07^{\mathrm{a}}$ & $531.23 \pm 580.43^{\mathrm{a}}$ & $5.09 \pm 6.72^{\mathrm{a}}$ & $10.76 \pm 12.51^{\mathrm{a}}$ & $16.06 \pm 14.29^{\mathrm{a}}$ & $42.32 \pm 37.34^{\mathrm{a}}$ & $61.46 \pm 43.87^{\mathrm{a}}$ \\
\hline $\mathrm{F}$ & $575.47 \pm 472.62^{\mathrm{b}}$ & $551.57 \pm 463.18^{\mathrm{b}}$ & $390.61 \pm 316.98^{\mathrm{b}}$ & $3.33 \pm 3.41^{\mathrm{b}}$ & $6.94 \pm 5.23^{b}$ & $12.26 \pm 10.31^{\mathrm{b}}$ & $31.31 \pm 25.25^{\mathrm{b}}$ & $38.21 \pm 28.91^{\mathrm{b}}$ \\
\hline \multicolumn{9}{|c|}{ Interaction Breed $\times$ Sex } \\
\hline \multicolumn{9}{|l|}{ DK } \\
\hline M & $2025.00 \pm 244.44^{\text {aa }}$ & $1866.67 \pm 229.49^{\text {aa }}$ & $1336.33 \pm 194.45^{\text {aa }}$ & $17.05 \pm 3.48^{\text {aa }}$ & $31.87 \pm 8.23^{\text {aа }}$ & $40.12 \pm 6.51^{\text {aa }}$ & $87.45 \pm 15.36^{\text {aa }}$ & $163.45 \pm 22.14^{\text {aa }}$ \\
\hline $\mathrm{F}$ & $1175.00 \pm 52.44^{\mathrm{ab}}$ & $1125.00 \pm 52.44^{\mathrm{ab}}$ & $785.42 \pm 39.83^{\mathrm{ab}}$ & $10.11 \pm 2.86^{\mathrm{ab}}$ & $18.19 \pm 8.03^{\mathrm{ab}}$ & $28.22 \pm 9.97^{\mathrm{ab}}$ & $54.87 \pm 17.16^{\mathrm{bb}}$ & $94.93 \pm 36.45^{\mathrm{ab}}$ \\
\hline \multicolumn{9}{|l|}{ GF } \\
\hline M & $889.17 \pm 102.49^{\mathrm{bb}}$ & $835.00 \pm 108.17^{\mathrm{bb}}$ & $581.67 \pm 91.96^{\mathrm{bb}}$ & $3.87 \pm 1.44^{\mathrm{b}}$ & $12.62 \pm 1.13^{\mathrm{bb}}$ & $19.47 \pm 6.38^{\mathrm{b}}$ & $56.65 \pm 6.68^{\mathrm{b}}$ & $58.12 \pm 7.31^{\text {ba }}$ \\
\hline $\mathrm{F}$ & $954.18 \pm 139.12^{\text {ba }}$ & $916.67 \pm 136.63^{\text {ba }}$ & $658.50 \pm 129.33^{\text {ba }}$ & $4.53 \pm 1.03^{\mathrm{b}}$ & $15.37 \pm 2.48^{\text {ba }}$ & $19.45 \pm 5.41^{\mathrm{b}}$ & $56.33 \pm 10.36^{\mathrm{a}}$ & $54.33 \pm 3.40^{\mathrm{bb}}$ \\
\hline
\end{tabular}

ab: Means on the same column with different superscripts and for the same variable are statistically significant $(\mathrm{P}<0.05)$.

$\mathrm{FW}=$ Fasted weight, BLW $=$ Bled weight, $\mathrm{DW}=$ Defeathered weight, $\mathrm{HW}=$ Heart weight, $\mathrm{LW}=$ Liver weight, GW= Gizzard weight, BLDW = Blood weight, HLW $=$ Head and Leg weight.

Table 2. Percentage of carcasses and organs of duck and guinea fowl as affected by breed and sex

\begin{tabular}{|c|c|c|c|c|c|c|c|c|}
\hline & & & & Variable & & & & \\
\hline Parameter & BLW (\%) & DFW (\%) & HW (\%) & LW (\%) & GW (\%) & BLDW (\%) & HLW (\%) & DRSW (\%) \\
\hline \multicolumn{9}{|l|}{ Breed } \\
\hline DK & $93.19 \pm 2.04^{\mathrm{b}}$ & $84.81 \pm 4.00^{\mathrm{b}}$ & $0.84 \pm 0.49^{\mathrm{a}}$ & $1.71 \pm 0.70$ & $2.36 \pm 0.56$ & $6.35 \pm 2.90^{\mathrm{a}}$ & $8.21 \pm 0.45^{\mathrm{a}}$ & $68.71 \pm 1.91$ \\
\hline GF & $94.90 \pm 1.82^{\mathrm{a}}$ & $86.84 \pm 3.74^{\mathrm{a}}$ & $0.49 \pm 0.00^{\mathrm{b}}$ & $1.55 \pm 0.56$ & $2.01 \pm 0.23$ & $5.28 \pm 1.91^{\mathrm{b}}$ & $6.20 \pm 0.84^{b}$ & $68.93 \pm 8.37$ \\
\hline \multicolumn{9}{|l|}{ SEX } \\
\hline M & $93.89 \pm 2.17^{\mathrm{b}}$ & $83.60 \pm 3.72^{\mathrm{b}}$ & $0.86 \pm 0.36^{\mathrm{a}}$ & $1.89 \pm 0.69$ & $2.32 \pm 0.45$ & $6.15 \pm 2.51^{\mathrm{a}}$ & $3.65 \pm 5.01$ & $69.68 \pm 3.87^{\mathrm{b}}$ \\
\hline $\mathrm{F}$ & $95.77 \pm 1.29^{\mathrm{a}}$ & $86.69 \pm 4.43^{\mathrm{a}}$ & $0.81 \pm 0.32^{\mathrm{b}}$ & $2.41 \pm 1.13$ & $2.48 \pm 0.57$ & $3.90 \pm 0.39^{\mathrm{b}}$ & $3.76 \pm 5.83$ & $70.36 \pm 7.95^{\mathrm{a}}$ \\
\hline \multicolumn{9}{|c|}{ Interaction Breed x Sex } \\
\hline \multicolumn{9}{|l|}{ DK } \\
\hline M & $92.02 \pm 2.40^{\mathrm{bb}}$ & $82.80 \pm 2.60^{\mathrm{bb}}$ & $0.88 \pm 0.90^{\mathrm{aa}}$ & $1.55 \pm 0.34$ & $1.98 \pm 0.12$ & $8.38 \pm 1.03^{\text {aa }}$ & $3.95 \pm 0.19^{\mathrm{a}}$ & $68.50 \pm 2.94^{\mathrm{a}}$ \\
\hline $\mathrm{F}$ & $95.54 \pm 2.50^{\text {ba }}$ & $86.99 \pm 1.70^{\mathrm{a}}$ & $0.81 \pm 0.65^{\mathrm{ab}}$ & $1.87 \pm 0.51$ & $2.76 \pm 0.52$ & $4.22 \pm 1.40^{\mathrm{b}}$ & $4.26 \pm 0.72^{\mathrm{a}}$ & $69.39 \pm 2.44^{\mathrm{b}}$ \\
\hline \multicolumn{9}{|l|}{ GF } \\
\hline M & $95.76 \pm 1.91^{\mathrm{ab}}$ & $86.75 \pm 3.66^{\mathrm{a}}$ & $0.43 \pm 0.11^{\mathrm{bb}}$ & $1.43 \pm 0.25$ & $2.16 \pm 0.31$ & $6.70 \pm 1.82^{\text {ba }}$ & $2.29 \pm 5.28^{\mathrm{b}}$ & $67.26 \pm 3.28^{\mathrm{bb}}$ \\
\hline $\mathrm{F}$ & $96.78 \pm 2.30^{\text {aa }}$ & $86.99 \pm 1.80$ & $0.49 \pm 0.05^{\mathrm{ba}}$ & $1.67 \pm 0.12$ & $1.83 \pm 0.47$ & $4.00 \pm 1.27^{\mathrm{b}}$ & $2.81 \pm 5.76^{\mathrm{b}}$ & $70.61 \pm 3.90^{\text {aa }}$ \\
\hline
\end{tabular}

ab: Means on the same column with different superscripts and for the same variable are statistically significant $(\mathrm{P}<0.05)$.

BLW $=$ Bled weight $(\%), \mathrm{DW}=$ Defeathered weight $(\%), \mathrm{HW}=$ Heart weight $(\%), \mathrm{LW}=$ Liver weight $(\%), \mathrm{GW}=$ Gizzard weight (\%), BLDW = Blood weight (\%), HLW = Head and Leg weight (\%), DRSW = Dressing Weight $(\%)$. 
Table 3. Weight of different cut-up parts (primal cuts) of duck and guinea fowl ad affect by breed and sex

\begin{tabular}{|c|c|c|c|c|c|c|c|}
\hline \multicolumn{8}{|c|}{ Variable } \\
\hline Parameter & Breast (g) & Thigh (g) & Drumstick (g) & Foreback (g) & Hindback (g) & Wing (g) & Neck (g) \\
\hline \multicolumn{8}{|l|}{ Breed } \\
\hline DK & $280.97 \pm 72.14^{\mathrm{a}}$ & $93.88 \pm 18.02^{\mathrm{a}}$ & $111.32 \pm 34.24^{\mathrm{a}}$ & $115.28 \pm 61.22^{\mathrm{a}}$ & $112.81 \pm 45.73^{\mathrm{a}}$ & $234.83 \pm 62.67^{\mathrm{a}}$ & $90.57 \pm 32.14^{\mathrm{a}}$ \\
\hline GF & $168.44 \pm 42.00^{\mathrm{b}}$ & $88.63 \pm 31.05^{\mathrm{b}}$ & $78.66 \pm 14.38^{\mathrm{b}}$ & $62.83 \pm 12.22^{\mathrm{b}}$ & $65.21 \pm 17.14^{\mathrm{b}}$ & $102.16 \pm 27.30^{b}$ & $63.85 \pm 13.68^{\mathrm{b}}$ \\
\hline \multicolumn{8}{|l|}{ SEX } \\
\hline M & $125.92 \pm 141.37^{\mathrm{a}}$ & $58.51 \pm 47.97^{\mathrm{a}}$ & $66.81 \pm 64.97^{\mathrm{a}}$ & $63.19 \pm 61.30^{\mathrm{a}}$ & $54.84 \pm 62.92^{\mathrm{a}}$ & $102.99 \pm 127.05^{\mathrm{a}}$ & $48.76 \pm 52.98^{\mathrm{a}}$ \\
\hline $\mathrm{F}$ & $107.16 \pm 73.34^{\mathrm{b}}$ & $48.44 \pm 41.87^{\mathrm{b}}$ & $47.82 \pm 39.18^{b}$ & $35.99 \pm 28.52^{\mathrm{b}}$ & $43.69 \pm 33.28^{\mathrm{b}}$ & $73.79 \pm 64.47^{b}$ & $29.94 \pm 26.28^{b}$ \\
\hline \multicolumn{8}{|c|}{ Interaction Breed x Sex } \\
\hline \multicolumn{8}{|l|}{$\mathrm{DK}$} \\
\hline M & $342.72 \pm 47.01^{\text {aа }}$ & $106.68 \pm 35.80^{\text {aa }}$ & $142.12 \pm 014.68^{\text {aa }}$ & $159.55 \pm 57.73^{\text {aa }}$ & $140.45 \pm 49.39^{\text {aa }}$ & $291.52 \pm 16.97^{\text {aa }}$ & $116.40 \pm 23.71^{\text {aa }}$ \\
\hline $\mathrm{F}$ & $219.22 \pm 13.12^{\mathrm{ab}}$ & $70.62 \pm 7.62^{\mathrm{bb}}$ & $80.75 \pm 9.30^{\mathrm{ab}}$ & $71.02 \pm 14.45^{\mathrm{ab}}$ & $85.17 \pm 18.12^{\mathrm{ab}}$ & $178.13 \pm 25.27^{\mathrm{ab}}$ & $64.73 \pm 10.42^{\mathrm{ab}}$ \\
\hline \multicolumn{8}{|l|}{ GF } \\
\hline M & $150.45 \pm 37.55^{\mathrm{bb}}$ & $93.00 \pm 13.82^{\mathrm{bb}}$ & $77.52 \pm 14.25^{\mathrm{bb}}$ & $58.37 \pm 15.39^{\mathrm{bb}}$ & $57.27 \pm 14.59^{\mathrm{bb}}$ & $93.58 \pm 17.73^{\mathrm{bb}}$ & $44.72 \pm 15.83^{\text {ba }}$ \\
\hline $\mathrm{F}$ & $186.43 \pm 42.62^{\mathrm{ba}}$ & $94.77 \pm 22.84^{\mathrm{aa}}$ & $79.57 \pm 15.78^{\text {ba }}$ & $67.30 \pm 16.61^{\text {ba }}$ & $72.97 \pm 16.89^{\text {ba }}$ & $110.73 \pm 33.90^{\text {ba }}$ & $42.98 \pm 12.62^{\mathrm{bb}}$ \\
\hline
\end{tabular}

ab: Means on the same column with different superscripts and for the same variable are statistically significant $(\mathrm{P}<0.05)$.

Table 4. Percentage of different cut-up parts (primal cuts) of duck and guinea fowl as influenced by breed and sex

\begin{tabular}{|c|c|c|c|c|c|c|c|}
\hline \multicolumn{8}{|c|}{ Variable } \\
\hline Parameter & Breast (\%) & Thigh (\%) & Drumstick(\%) & Foreback $(\%)$ & Hindback (\%) & Wing (\%) & Neck $(\%)$ \\
\hline \multicolumn{8}{|l|}{ Breed } \\
\hline DK & $27.46 \pm 1.44$ & $8.46 \pm 2.01^{\mathrm{b}}$ & $10.76 \pm 1.25^{\mathrm{b}}$ & $10.59 \pm 3.09$ & $10.83 \pm 2.27$ & $21.70 \pm 3.68^{\mathrm{a}}$ & $8.54 \pm 1.26^{\mathrm{a}}$ \\
\hline GF & $27.18 \pm 3.66$ & $15.29 \pm 1.17^{\mathrm{a}}$ & $12.35 \pm 2.03^{\mathrm{a}}$ & $10.35 \pm 1.40$ & $10.72 \pm 1.61$ & $15.53 \pm 3.69^{\mathrm{b}}$ & $7.35 \pm 2.96^{b}$ \\
\hline \multicolumn{8}{|l|}{ SEX } \\
\hline M & $29.68 \pm 6.07$ & $10.51 \pm 4.52$ & $10.19 \pm 3.33$ & $10.38 \pm 2.64$ & $10.35 \pm 1.89$ & $20.79 \pm 5.16$ & $7.50 \pm 2.74$ \\
\hline $\mathrm{F}$ & $29.54 \pm 2.98$ & $10.32 \pm 3.29$ & $9.51 \pm 2.86$ & $10.23 \pm 1.92$ & $11.01 \pm 2.34$ & $20.19 \pm 5.08$ & $7.11 \pm 1.55$ \\
\hline \multicolumn{8}{|c|}{ Interaction Breed $\mathrm{x}$ Sex } \\
\hline \multicolumn{8}{|l|}{ DK } \\
\hline M & $26.39 \pm 0.96^{\mathrm{a}}$ & $7.94 \pm 1.33^{\mathrm{bb}}$ & $11.05 \pm 0.88^{\mathrm{b}}$ & $11.97 \pm 2.17^{\text {aa }}$ & $10.61 \pm 2.40^{\mathrm{a}}$ & $22.63 \pm 1.03^{\mathrm{a}}$ & $8.68 \pm 2.92^{\mathrm{aa}}$ \\
\hline $\mathrm{F}$ & $28.53 \pm 0.70^{\mathrm{a}}$ & $9.18 \pm 0.78^{\text {ba }}$ & $10.45 \pm 0.88$ & $9.21 \pm 1.70^{\mathrm{ab}}$ & $11.05 \pm 2.00$ & $23.27 \pm 1.03^{\mathrm{a}}$ & $7.73 \pm 3.71^{\mathrm{a}}$ \\
\hline \multicolumn{8}{|l|}{ GF } \\
\hline M & $25.88 \pm 4.04^{\mathrm{b}}$ & $16.13 \pm 0.45^{\text {aa }}$ & $13.39 \pm 0.73^{\text {aa }}$ & $10.18 \pm 1.84^{\mathrm{b}}$ & $9.35 \pm 0.65^{\mathrm{bb}}$ & $15.68 \pm 1.60^{\mathrm{b}}$ & $8.46 \pm 2.50^{\mathrm{a}}$ \\
\hline $\mathrm{F}$ & $28.51 \pm 1.92^{\mathrm{a}}$ & $14.44 \pm 0.88^{\mathrm{ab}}$ & $11.30 \pm 2.04^{\mathrm{b}}$ & $10.53 \pm 1.68^{\mathrm{a}}$ & $11.59 \pm 0.60^{\mathrm{a}}$ & $15.38 \pm 2.80^{\mathrm{b}}$ & $6.61 \pm 1.68^{\mathrm{bb}}$ \\
\hline
\end{tabular}

ab: Means on the same column with different superscripts and for the same variable are statistically significant $(\mathrm{P}<0.05)$.

\section{Conclusion}

The only plausible approach to achieving the noble goal of providing quality protein for all in the less developed countries is vigorous development of the poultry industry. This is because it is the fastest means to bridge protein deficiency gap due to short generation interval of poultry species. In order to realize this goal fully, other poultry species other than domestic fowl has to be considered such as Duck and Guinea fowl (GF) that are found in 
ecological zones of these developing countries, Nigeria inclusive. In this study comparative effects of breed and sex on carcass and organs characteristics of Duck and Guinea fowl in Abeokuta metropolis were investigated. It was observed that both breed and sex had influence on carcass and organs of the two brids with Duck having higher carcass, organs, weight and cut-up parts, while males of the two birds had higher carcass as well as primal cuts percentage weight. Also female GF elicited high percentage of some cut-up parts like the males. It is recommended that the two birds be well incorporated into commercial poultry farming since they have high carcass and edible organs percentage weight that compared favourably with the domestic fowl.

\section{References}

Aduku, A. O., \& Olukosi, J. O. (1990). Rabbit Management in the Tropics. Living Book Series, G.U Publications Abuja, Nigeria. pp. 2-5.

Aduku, A. O., \& Olukosi, J. O. (2000). Animal Products Processing and Handling in the Tropics. Living Book Series, G.U. Publications, Abuja, Nigeria, pp. 121-126.

Atteh, J. O. (2004). Theory and Practise of Poultry Production. (1st ed.) (p. 241). ADEK Pinters, Sabo line, Ilorin, Kwara State, Nigeria.

Carew, B. A. R., Ajetunmobi, A. W., Elesin, F. O., \& Dacosta, F. A. (1998). Carcass quality of Poultry Species in Lagos Metropolis. Proc. of Silver Anniversary NSAP/WASAP Inaugural Conf. March 21-26. pp. 462-463.

FAO. (2006). Food and Agriculture Organisation of the United Nations' Bulletin of Statistics. The Merk Veterinary Manual, (9th ed.) (pp. 138-139). USA: Merk and Co. Inc.

Gbadamoshi, A. J., \& Egbunike, G. N. (1999). Studies on Cock Semen: Effect of Frequent ejaculation and Breed on Physical Characteristics Trop. J, Anim. Sci, 1,137-164.

Ireobi, O. N., Hyginus, C. M., Adeowo, J. A., \& Adebambo, O. A. (1999). Egg quality characteristics of Four local Poultry species in Nigeria. Trop. J. Anim. Sci., 37-42.

Nwachucku, E. N. (1998). Sexual dimorphism of some conformation traits and carcass composition of Muscovey duckling raised intensively. Proc. Silver Anniversary of Nig. Soc. Anim. Prod. West African Soc. Anim. Prod. Inaugural Conf. March 21-28.

Nwagu, B. I., \& Alawa, C. B. I. (1995). Guinea fowl Production in Nigeria. World's Poultry J., 51, 261-270. http://dx.doi.org/10.1079/WPS19950018

Okubanjo, A. O. (1997). Meat characteristics of Singed and Conventionally dressed chevon carcasses. Food Sci. Technol., 34(6), 494-497.

Omojola, A. B. (2007). Carcass and Organoleptic Characteristics of Duck meat as influenced by breed and sex. Inter. J. Poultry Sci., 6(5), 329-334. http://dx.doi.org/10.3923/ijps.2007.329.334

Omojola, A. B., Adesehinwa, A. O. K., Madu, H., \& Attah, S. (2004). Effect of Sex and Slaughter weight on broiler chicken carcass. Food Agric. Environ, 2, 61-63.

SAS. (2002). Statistical Analysis System. SAS Institute User's Guide Version 9 Carry, N.C. USA.

Yusuf, R. O. (1995). Meat yield and quality characteristics of pigeon, guinea fowl and duck. Unpublished B.Sc Thesis in the Department of Animal Science, University of Ibadan, Nigeria.

\section{Copyrights}

Copyright for this article is retained by the author(s), with first publication rights granted to the journal.

This is an open-access article distributed under the terms and conditions of the Creative Commons Attribution license (http://creativecommons.org/licenses/by/3.0/). 